\title{
Hubungan Gaya Mengajar Dosen dalam Proses Pembelajaran dengan Motivasi Belajar Mahasiswa Fakultas Psikologi dan Pendidikan Universitas Al Azhar Indonesia
}

\author{
Eny suwarni \\ Program Studi Psikologi, Fakultas Psikologi dan Pendidikan, \\ Universitas Al Azhar Indonesia, Jl.Sisingamangaraja, Jakarta 12110 \\ E-mail: enysuwarni@ymail.com
}

\begin{abstract}
Abstrak - Penelitian ini bertujuan untuk memberikan gambaran hubungan Gaya Mengajar Dosen dengan Motivasi Belajar Mahasiswa di fakultas psikologi \& Pendidikan Universitas Al Azhar Indonesia. Penelitian ini merupakan penelitian lapangan (field research) dengan subjek yang diamati berbeda-beda (cross sectional), dan bersifat kuantitatif. Pengumpulan data dalam penelitian ini dengan menggunakan kuesioner berupa skala. Teknik analisis yang digunakan untuk mengolah data penelitian yaitu validitas-reliabilitas, uji normalitas dan product moment. SPSS 16. Sampel penelitian yang dipakai adalah 79 mahasiswa . Hasil penelitian yang diperoleh adalah terdapat ada hubungan yang negatif antara Gaya Mengajar Elementery, Intermediate, Advanced, dan creative evaluative dengan Motivasi Belajar Mahasiswa di Fakultas Psikologi \& Pendidikan Universitas Al Azhar Indonesia Jakarta. Kesimpulan dari hasil penelitian ini adalah Gaya Mengajar Dosen berkorelasi secara negative dengan Motivasi Belajar Mahasiswa.
\end{abstract}

Abstrack - This research focused on describing correlation between Teaching Style with Learning Motivation of Education \& Psychology Al Azhar University students. Previous researches showed significant negatif correlation between Teaching Style Elementary, Intermediate, Advanced, dan creative evaluative with learning motivation students. This research was using learning motivation Scale and teaching style that developed by Bloom as data gathering instrument for 79 subjects. Using independent product moment for processing data analysis, the result showed that there was significant negatif correlation between Teaching Style Elemantary, Intermediate, Advanced and Creative-evaluative with learning motivation students. It can be concluded that Teaching Style variable also played important to increase student motivations.

Keywords - Teaching Style, Learning Motivation

\section{PENDAHULUAN}

$\mathrm{P}$ endidikan adalah usaha sadar dan terencana untuk mewujudkan suasana belajar dan proses pembelajaran agar peserta didik secara aktif mengembangkan potensi dirinya untuk memiliki kekuatan spiritual keagamaan, pengendalian diri, kepribadian, kecerdasan, akhlak mulia, serta keterampilan yang diperlukan dirinya dan masyarakat. Menurut survei Political and Economic Risk Consultant (PERC), kualitas pendidikan di Indonesia berada pada urutan ke-12 dari 12 negara di Asia. Posisi Indonesia berada di bawah Vietnam. Data yang dilaporkan The World Economic Forum Swedia (2000), Indonesia memiliki daya saing yang rendah, yaitu hanya menduduki urutan ke-37 dari 57 negara yang disurvei di dunia (www.idonbiu.com/2009/10).

Kualitas pendidikan di Indonesia saat ini sangat memprihatinkan. Ini dibuktikan antara lain dengan data UNESCO (2000) tentang peringkat Indeks Pengembangan Manusia (Human Development Index), yaitu komposisi dari peringkat pencapaian pendidikan, kesehatan, dan penghasilan per kepala yang menunjukkan, bahwa indeks pengembangan manusia Indonesia makin menurun. Di antara 174 negara di dunia, Indonesia menempati urutan ke- 
102 (1996), ke-99 (1997), ke-105 (1998), dan ke109 (1999). Menurut survei Political and Economic Risk Consultant (PERC), kualitas pendidikan di Indonesia berada pada urutan ke-12 dari 12 negara di Asia. Posisi Indonesia berada di bawah Vietnam. Data yang dilaporkan The World Economic Forum Swedia (2000), Indonesia memiliki daya saing yang rendah, yaitu hanya menduduki urutan ke-37 dari 57 negara yang disurvei di dunia. Dan masih menurut survai dari lembaga yang sama Indonesia hanya berpredikat sebagai follower bukan sebagai pemimpin teknologi dari 53 negara di dunia. Memasuki abad ke- 21 dunia pendidikan di Indonesia menjadi heboh. Kehebohan tersebut bukan disebabkan oleh kehebatan mutu pendidikan nasional tetapi lebih banyak disebabkan karena kesadaran tentang bahaya keterbelakangan pendidikan di Indonesia. Perasan ini disebabkan karena beberapa hal yang mendasar. Salah satunya adalah memasuki abad ke-21 gelombang globalisasi dirasakan kuat dan terbuka. Kemajuan teknologi dan perubahan yang terjadi memberikan kesadaran baru bahwa Indonesia tidak lagi berdiri sendiri. Indonesia berada di tengah-tengah dunia yang baru, dunia terbuka sehingga orang bebas membandingkan kehidupan dengan negara lain.

Pendidikan memang telah menjadi penopang dalam meningkatkan sumber daya manusia Indonesia untuk pembangunan bangsa. Rendahnya mutu pendidikan menghambat penyediaan sumber daya manusia yang mempunyai keahlian dan keterampilan untuk memenuhi pembangunan bangsa di berbagai bidang. Penyebab rendahnya mutu pendidikan di Indonesia antara lain pada masalah efektifitas, efisiensi dan standarisasi pengajaran. Hasil survei ini menggambarkan dampak terakhir dapat dirasakan sebagai output pendidikan adalah rendahnya kompetensi sumber daya manusia Indonesia, khususnya dari lulusan Perguruan Tinggi. Pertanyaan mendasar dari fenomena ini adalah bagaimana proses pendidikan yang ada selama ini, khususnya pendidikan di Perguruan tinggi? Banyak faktor penyebab rendahnya kompetensi lulusan Perguruan Tinggi, salah satunya adalah tingkat kemampuan Dosen dalam proses pembelajaran, tercermin dari gaya mengajarnya. Aspek yang harus dimiliki seorang Dosen dalam mengajar yaitu niat, tanggung jawab, komitmen, kiat, giat dan doa untuk membawa mahasiswa mencapai tujuan pembelajaran. Bagi mahasiswa aspek yang melandasi mahasiswa untuk belajar yaitu niat, minat, kiat, giat, komitmen dan tanggung jawab dan doa. Menurut Purwanto (2007) strategi pembelajaran yang diberikan Dosen pada mahasiswa berdasarkan pendekatan konstruktif (constructivist - approach) lebih menekankan pada pembelajar/mahasiswa (leaner-centered).

Pendekatan ini menyatakan pentingnya mahasiswa sebagai individu secara aktif membangun pengetahuan dan pemahaman melalui bimbingan dari Dosen. Sebaliknya pendekatan pembelajaran langsung (direct instruction approach) menyatakan perlu pendekatan terstruktur dan berpusat pada mahasiswa. Dosen hanya memberikan arahan dan pengendalian. Harapan Dosen tinggi untuk kemajuan mahasiswa, waktu maksimum yang dihasilkan oleh mahasiswa untuk menyelesaikan tugas akademis, dan ada upaya-upaya Dosen untuk meminimalisasi pengaruh negatif dalam proses pembelajaran. Dengan kata lain dalam proses pembelajaran yang berpusat pada Dosen, mahasiswa akan pasif dalam proses pembelajaran. Dosen banyak menekankan pada teori dan konsep yang perlu dipahami oleh mahasiswa, dan proses pembelajaran lebih berada dalam situasi kelas. Proses pembelajaran ini hanya mengembangkan unsur kognitif mahasiswa. Sedangkan proses pembelajaran yang berpusat pada mahasiswa, menekankan pada keaktifan mahasiswa. Proses pembelajaran pada mahasiswa diberikan dalam bentuk belajar memecahkan masalah, membuat project and report, survey, kunjungan industri dan studi lapangan. Pada mahasiswa akan berkembang unsur kognitif, psikomotor dan afektif. Apapun metode yang diberikan oleh Dosen, yang menjadi pertanyaan adalah bagaimana gaya mengajar Dosen dalam proses pembelajarannya ? Dosen lebih berperan sebagai fasilitator, memberikan pengetahuan (transfer of knowledge) pada mahasiswa. Mahasiswa dianggap mampu untuk menjalankan tugasnya sebagai individu yang sedang menuntut ilmu. Ada empat Gaya pembelajaran Dosen muncul di saat mengajar yaitu: (1). Dosen elementary, lebih memberikan understanding, comprehension dan memorizing pada mahasiswa. Cirinya adalah banyak menggunakan "what, when, where, penyampaian informasi, menjelaskan tugas, pekerjaan rumah, (2). Dosen intermediate, menekankan pada critical thinking and doing. Ciri dalam proses pembelajaran adalah menekankan pada how, why and application, penjelasan, dialog, diskusi, kasus, presentasi. (3). Dosen advanced, dengan ciri menekankan pada problem solving, why, analysis, synthesis dan idea. Banyak membahas kasus, proyek,survey, studi lapangan presentasi dan seminar.(4) Dosen creative-evaluative, mengajak mahasiswa untuk " thinking out of the box. 
Mengevaluasi, innovation, kasus, diskusi, penelitian, proyek, karya ilmiah, jurnal dan seminar. (Once.2008). Gaya yang diberikan Dosen saat mengajar akan dirasakan oleh mahasiswa. Berdasarkan interview kepada lebih kurang 20 mahasiswa psikologi Universitas Al Azhar Indonesia bahwa Gaya mengajar dosen membuat mereka bisa menjadi malas belajar atau senang sekali untuk belajar. Kemungkinan yang terjadi adalah apabila mereka menganggap bahwa gaya mengajar dosen memudahkan bagi mereka memahami materi perkuliahan akan memotivasi mereka untuk memiliki rasa ingin tahu yang lebih tinggi. Sebaliknya ketika mereka menganggap bahwa cara mengajar dosen menyulitkan mereka dalam memahami materi perkuliahan, maka akan menurunkan motivasi untuk mengetahui lebih banyak tentang materi perkuliahan. Hasil penelitian Suwarni, E (2008) menyimpulkan bahwa kesadaran pandangan positif pada umpan balik dari dosen, dan mahasiswa yang aktif mencari informasi baru, merupakan aspek dalam motivasi belajar yang signifikan, artinya aspek ini menjadi pendorong /memotivasi mereka untuk mencapai prestasi yang baik dalam proses pembelajaran. Sedangkan hasil penelitian (Roebyantho,S.H 2008) menunjukkan ada hubungan antara minat membaca mahasiswa terhadap materi yang disampaikan Dosen dengan prestasi yang dicapai. Dari hasil penelitian ini menggambarkan bahwa motivasi dan prestasi yang diperoleh mahasiswa tidak terlepas dari gaya mengajar Dosen dalam proses pembelajaran. Universitas Al Azhar Indonesia merupakan Perguruan Tinggi yang akan mencetak individu mampu untuk berpikir kritis, dan menguasai bidang ilmunya. Gaya mengajar Dosen dalam proses pembelajaran menjadi suatu "core" yang perlu dikaji secara jelas. Dari fenomena ini menjadi menarik untuk diteliti, dalam proses pembelajaran yang telah dilakukan, apakah ada hubungan antara gaya mengajar Dosen dengan motivasi belajar mahasiswa?

\section{TINJAUAN PUSTAKA}

Dalam proses pembelajaran Dosen sebagai figur pentransfer ilmu pada mahasiswa, memiliki tugas pokok antara lain ia harus mampu dan cakap merencanakan, mengevaluasi dan membimbing kegiatan pembelajaran. Oleh karena itu dalam proses pembelajaran ada komponen utama yaitu:

1. Siswa, dengan karakteristik yang dimilikinya, baik dari dalam diri atau dari luar dirinya.
2. Tujuan, ialah apa yang diharapkan dari proses pembelajaran, merupakan seperangkat tugas atau tuntutan yang harus nampak dalam perilaku dan merupakan karakteristik kepribadian siswa.

3. Guru/dosen, ialah orang dewasa yang karena jabatannya secara formal selalu mengusahakan terciptanya situasi yang tepat sehingga memungkinkan terciptanya proses pengalaman belajar (learning experience) pada siswa, dengan mengerahkan segala sumber (learning resources) dan menggunakan strategi pembelajaran (teaching-learning strategis) yang tepat. Proses pembelajaran dapat diartikan sebagai suatu interaksi antara siswa dengan Dosen dalam rangka mencapai tujuan (Abin, 1990).Dari definisi ini maka proses pembelajaran tidak hanya berlangsung satu arah (one way system) melainkan terjadi secara timbal balik (interaktif, two ways trafic system) dimana kedua pihak berperan dan berbuat secara aktif di dalam suatu kerangka berpikir (frame of reference). Tujuan interaksi belajar tersebut merupakan titik temu dan bersifat mengikat serta mengarahkan aktivitas dari kedua belah pihak.

\subsection{Model Mengajar}

Menurut Joice and Well (dalam Gage dan Berliner, 1995) model mengajar berdasarkan orientasinya:

1. Information procesing orientation, mencakup semua metode mengajar yang titik beratnya mengembangkan kemampuan intelektual atau kognitif siswa dengan menggunakan prosesproses deduktif, pemecahan masalah.

2. Social interaction orientation, mencakup berbagai metode mengajar yang tujuannya diarahkan kepada kemampuan kerjasama secara kooperatif, saling memahami dengan kelompok sosial yang ada dalam lingkungan.

3. Person orientation, mencakup metode mengajar yang sasarannya memberikan kesempatan perkembangan pribadi, kreativitas, kehangatan atau vitalitas (semangat hidup) setiap siswa.

4. Behavior modification orientation, mencakup berbagai metode mengajar yang ditujukan dan dititik beratkan pada perubahan perilaku ke arah yang diharapkan guru/dosen.

\subsection{Gaya Mengajar}

Ada empat Gaya pembelajaran Dosen yang muncul di saat mengajar yaitu: 
1. Dosen elementary, lebih memberikan understanding, comprehension dan memorizing pada mahasiswa. Ciri yang muncul adalah banyak menggunakan "what, when, where", penyampaian informasi, menjelaskan tugas, pekerjaan rumah,

2. Dosen intermediate, menekankan pada critical thinking and doing. Ciri yang muncul dalam proses pembelajaran adalah menekankan pada how, why and application, penjelasan, dialog, diskusi, kasus, presentasi.

3. Dosen advanced, dengan ciri ini menekankan pada problem solving, why, analysis, synthesis dan idea. Banyak membahas kasus, proyek, survey, studi lapangan presentasi dan seminar.

4. Dosen creative, mengajak mahasiswa untuk thinking out of the box. Mengevaluasi, innovation, kasus, diskusi, penelitian, proyek, karya ilmiah, jurnal dan seminar.

Manusia itu sendiri yang dapat mempengaruhi individu dalam belajar. Faktor-faktor yang berasal dari dalam individu (intern), dapat digolongkan ke dalam dua golongan:

1. Faktor-faktor fisiolgis, seperti adanya unsurunsur fisiologis yang menderita sakit atau cacat.

2. Faktor-faktor psikologis.

Thomas $F$ staton dalam sardiman A.M menguraikan enam macam faktor psikologis, antara lain: Motivasi, Konsentrasi, Reaksi, Organisasi, Pemahaman, Ulangan. Disamping enam macam factor psikologis yang di uraikan oleh Thomas F.Staton, (dalam Sardiman A. M, 2001) masih ada yang mengklasifikasikan faktor-faktor psikologis dalam belajar, yaitu:

1. Perhatian, maksudnya adalah pemusatan energi pisikis yang tertuju kepada suatu objek pelajaran atau dapat dikaitkan sebagai banyak sedikitnya kesadaran yang menyertai aktivitas belajar.

2. Pengamatan, adalah cara mengenal dunia riil, baik dirinya sendiri maupun lingkungan dengan segenap panca indera.

3. Tanggapan, adalah gambaran/berkas yang tinggal dalam ingatan setelah orang melakukan pengamatan.

4. Fantasi, adalah sebagai kemampuan untuk membentuk tanggapan-tanggapan baru berdasarkan atas tangapan yang ada, atau dapat dikatakan sebagai suatu fungsi yang memungkinkan individu untuk berorientasi dalam alam imajiner, menerobos dunia realitas.

5. Ingatan, adalah kecakapan untuk menerima, menyimpan dan memproduksi kesan-kesan di dalam belajar.

6. Berpikir, merupakan aktivitas mental untuk dapat merumuskan pengertian, mensintesis dan menarik kesimpulan.

7. Bakat, adalah salah satu kemampuan manusia untuk melakukan suatu kegiatan dan sudah ada sejak manusia itu ada.

8. Motif, motivasi.

\subsection{Motivasi Belajar}

Johnson \& Jhonson (dalam Woolfolk, 1988) mendevinisikan motivasi belajar adalah kecenderungan siswa untuk bekerja keras atas aktivitas belajar dalam mencapai prestasi belajarnya.

W.S Winkel (1996) dalam bukunya psikologi pengajaran menyatakan motivasi belajar adalah keseluruhan daya penggerak pisikis di dalam diri siswa yang menimbulkan kegiatan belajar, menjamin kelangsungan kegiatan belajar dan memberikan arah pada kegiatan belajar itu demi mencapai suatu tujuan. Dikatakan "keseluruhan", karena pada umumnya ada beberapa motif yang bersama-sama menggerakan siswa untuk belajar.

Jare Brophy (1988) mendefinisikan motivasi belajar siswa adalah kecenderungan untuk bekerja keras atau aktivitas yang disebabkan dengan suatu keyakinan bahwa mereka berguna (the tendency to work hard on academic activities because one believes they are worthwhile). Dalam arti bahwa siswa memiliki kecenderungan untuk menemukan aktivitas akademik yang bermakna danberguna serta mencoba mendapatkan manfaat yang diharapkan.

\subsubsection{Fungsi motivasi belajar}

Motivasi sangat diperlukan dalam belajar. "Motivation is an essential condition of learning". Hasil belajar akan menjadi optimal, kalau ada motivasi. Makin tepat motivasi yang diberikan, akan makin berhasil pula pelajaran itu. Jadi motivasi senantiasa menentukan intensitas usaha belajar bagi siswa.

Perlu ditegaskan, bahwa motivasi bertalian dengan suatu tujuan sehubungan dengan hal tersebut ada tiga fungsi motivasi: 
1. Mendorong manusia untuk berbuat, jadi sebagai pengerak atau motor yang melepaskan energy.

2. Menentukan arah perbuatan, yakni kearah tujuan yang hendak dicapai.

3. Menyeleksi perbuatan, yakni menentukan perbuatan-perbuatan apa yang harus dikerjakan yang serasi guna mencapai tujuan.

Disamping itu, ada juga fungsi-fungsi lain. Motivasi dapat berfungsi sebagai pendorong usaha dan pencapaian prestasi. Adanya motivasi yang baik dalam belajar akan menunjukan hasil yang baik. Dengan kata lain bahwa dengan adanya usaha yang tekun dan terutama disadari adanya motivasi, maka seseorang yang belajar itu akan dapat melahirkan prestasi yang baik. Intensitas motivasi seseorang akan sangat menentukan tingkat pencapaian prestasi belajarnya.

\subsubsection{Indikator Dalam Motivasi Belajar}

Menurut Johnson \& Johnson (dalam Woolfolk, 1988) ada beberapa ciri tentang motivasi yang dapat dijadikan indikator dalam motivasi belajar:

1. Memiliki perencanaan dalam setiap tindakan.

2. Tindakan terfokus pada pencapaian tujuan yang diinginkan.

3. Memiliki rencana belajar yang menyeluruh dan berjuang untuk merealisasikan tujuan.

4. Memanfaatkan umpan balik yang konkret dalam semua kegiatan yang dilakukan.

5. Aktif dalam mencari informasi baru.

6. Bangga dan puas terhadap prestasi.

7. Tidak cemas dan takut gagal.

Apabila seseorang telah memiliki ciri-ciri di atas, berarti seseorang itu Selalu memiliki motivasi yang cukup kuat. Siswa yang memiliki motivasi rendah mereka akan menunjukan perilaku belajar yang tidak baik. Aktivitas belajar yang tidak menentu dan tanpa perencanaan, tidak menghargai pentingnya prestasi, kurang menghargai dan menerima umpan balik dari para pengajar, tidak memiliki rasa ingin tahu yang tinggi, dan mengalami kecemasan serta ketakutan dalam aktivitas belajar.

\subsubsection{Faktor-Faktor yang mempengaruhi motivasi belajar}

Motivasi belajar memiliki sejumlah unsur yang relevan bagi pertahanan motivasi tersebut. Hal ini dikemukakan oleh Brophy (dalam Woolfolk, 1980), bahwa terdapat faktor-faktor yang dapat meningkatkan motivasi belajar, di antaranya:
1. Kondisi kelas

Adapun kondisi kelas yang akan meningkatkan motivasi belajar adalah pertama, kelas relatif terorganisasi dan bebas dari gangguan yang menetap dan kekacauan. Kedua, pengajar harus sabar, suportif, dan tidak mempersulit siswa yang membuat kesalahan. Setiap orang dalam kelas harus memahami kesalahan sebagai kesempatan untuk belajar (Clifford, 19901991). Ketiga, mengerjakan sesuatu yang menentang dan masuk akal serta layak, jika mengerjakan sesuatu yang terlalu mudah atau terlalu sulit untuk dipelajari, siswa akan memiliki motivasi belajar rendah, mereka akan terfokus pada akhir belajar, bukan atas belajar. Keempat, tugas pelajaran harus autentik (Brophy, 1983; Brophy \& Kher, 1996; Stipek, 1993).

2. Membangun Kepercayaan dan Harapan Positif Salah satu faktor penting dalam membangun harapan yang positif yaitu keberhasilan masa lalu. Sedikitnya dorongan dan kegembiraan dapat menggantikan penyelesaian nyata. Perkembangan sesungguhnya dapat dipastikan sebagai berikut :

a. Mulai bekerja berdasarkan kemauan siswa dan bergerak dari hal yang dasar.

b. Meyakini tujuan belajar secara jelas, spesifik, dan mungkin diraih dalam waktu dekat.

c. Menekankan pada perbandingan diri, bukan membandingkan dengan yang lain.

d. Mampu meningkatkan kemampuan akademik siswa dan tugas yang spesifik.

e. Model penyelesaian masalah yang baik, khususnya ketika dihadapkan pada beberapa pendekatan yang dapat menyelesaikan permasalahan.

f. Mengetahui dan Memahami Nilai Belajar Pelajaran dapat menggunakan strategi motivasi instrinsik atau ekstrinsik. Hal yang harus diperhatikan dalam hal ini adalah masalah usia. Pada anak biasanya lebih tergesa-gesa, terfokus pada hal yang nyata, memiliki kesulitan dalam melihat aktivitas yang dihubungkan dengan tujuan jangka panjang, seperti memperoleh pekerjaanyang cocok. Pada orang dewasa, kemampuan kognitif untuk berpikir abstrak dan apa yang dia pelajari sekarang berhubungan denan tujuan dan kemugkinan di masa yan akan datang, sehingga nilai guna menjadi sangat penting untuk mahasiswa (Eccles \& Wigfield, 1985). 


\subsection{Hubungan Gaya Mengajar dengan Motivasi Belajar}

Pada dasarnya dalam motivasi mengandung sejumlah nilai. Motivasi menentukan tingkat keberhasilan atau gagalnya kegiatan belajar siswa. Belajar tanpa motivasi sulit untuk mencapai keberhasilan secara optimal.Pembelajaran yang bermotivasi pada hakikatnya adalah pembelajaran yang sesuai dengan kebutuhan, dorongan, motif, dan minat yang ada pada diri siswa. Pembelajaran yang bermotivasi menuntut kreativitas dan imajinasi guru untuk berupaya secara sungguhsungguh mencari cara yang relevan dan serasi guna membangkitkan dan memelihara motivasi belajar siswa.

Motivasi belajar bagi individu merupakan daya penggerak untuk bertingkah laku dalam belajar. Ketika daya penggerak ini diperlukan dalam proses belajar berarti tujuan dari bertingkah laku terarah pada prestasi yang diperoleh dalam belajar. Proses pembelajaran ini akan melibatkan dosen dan mahasiswa, yang saling berinteraksi. Semua aktivitas dosen dalam melakukan proses pembelajaran berhubungan dengan motivasi mahasiswa dalam mengikuti pelajaran yang diberikan.

Berbagai gaya mengajar yang dilakukan dosen ketika mentransfer ilmu pada mahasiswa, mereka akan termotivasi ketika ada dorongan, kebutuhan dari dalam dirinya untuk mencapai tujuan berupa pemahaman terhadap materi pelajaran yang diberikan. Ketika mahasiswa memiliki motivasi belajar akan tergambar dari perencanaan belajar yang mereka buat. Ada tujuan yang jelas yang menyebabkan mereka mau belajar. Ada keinginan untuk merealisasikan tujuan. Jika dosen memberikan umpan balik, mereka akan memanfaatkannya untuk mencari informasi baru, dan kebanggaan dan kepuasan akan muncul jika dapat berprestasi. Tampilan tingkah laku mereka juga menunjukkan tidak takut gagal dan cemas jika mereka gagal, karena selalu ada daya pendorong untuk mencapai prestasi ke arah yang lebih baik. Gaya mengajar yang digunakan dosen menjadi penting untuk memunculkan motivasi belajar mahasiswa. Motivasi belajar bagi mahasiswa merupakan daya penggerak untuk bertingkah laku dalam belajar. Ketika daya penggerak ini diperlukan dalam proses belajar berarti tujuan dari bertingkah laku terarah pada prestasi yang diperoleh dalam belajar.

\section{METODE PENELITIAN}

Dalam bab ini akan dibahas tentang hal-hal yang mencakup tentang bagaimana penelitian ini dilaksanakan.

\subsection{Rancangan Penelitian}

Rancangan penelitian yang akan digunakan adalah penelitian korelasional yaitu untuk mengetahui hubungan antara satu variabel dengan variabel lainnya dengan cara mengukur setiap variabel kemudian dilihat korelasinya atau sejauh mana keterkaitan antar variabel dengan bantuan metode statistik.

\subsection{Variabel Penelitian}

Variabel yang berperan dalam penelitian ini adalah:

1. Gaya Mengajar Dosen dalam proses pembelajaran $(\mathrm{X})$

2. Motivasi belajar $(\mathrm{Y})$

\subsection{Definisi Operasional Variabel}

1. Gaya mengajar Dosen dalam proses pembelajaran adalah: gaya yang dimunculkan dosen dalam mengajar diberikan pada mata kuliah yang diajarkan pada mahasiswa. Ada empat gaya: elementary, intermediate, advanced dan creative.

2. Motivasi belajar dalam penelitian ini adalah dorongan mahasiswa Fakultas Psikologi UAI untuk memiliki kesadaran dalam belajar, membuat perencanaan belajar, terfokus pada pencapaian tujuan,dapat memanfaatkan umpan balik yang diberikan Dosen,aktif dalam mencari informasi,dengan rasa ingin tahu yang tinggi, puas dan bangga pada prestasi, dan tidak takut gagal. Motivasi belajar dikatakan tinggi jika rata-rata motivasi belajar menunjukkan nilai skor yang tinggi pada skala motivasi belajar dan sebaliknya motivasi belajar dikatakan rendah jika rata-rata motivasi belajar menunjukkan nilai skor yang rendah bila diukur dengan skala motivasi belajar.

\subsection{Populasi dan Subjek Penelitian}

Populasi dalam penelitian ini adalah mahasiswa Fakultas Psikologi Universitas Al Azhar Indonesia. Subjek penelitiannya ditetapkan dengan menggunakan teknik random sampling. Teknik sampling ini adalah suatu cara pengambilan sampel dimana subyek dalam suatu populasi mempunyai 
kesempatan yang sama untuk menjadi subjek penelitian. Teknik ini dipilih berdasarkan kemungkinan pelaksanaan dan kekuatan generalisasi yang dimilikinya.

Subjek penelitian yang digunakan dalam penelitian ini adalah 79 mahasiswa dan 14 Dosen Jurusan Healing Konseling, Jurusan Pendidikan anak Usia Dini, dan Jurusan Psikologi.

\subsection{Instrumen Pengambilan Data}

1. Alat Ukur Gaya Mengajar Dosen: Alat ukur yang digunakan untuk mengukur metode mengajar Dosen diperoleh dari gaya mengajar dosen pada mata kuliah yang diajarkan. Alat pengumpulan data yang dipergunakan dalam penelitian ini adalah kuesioner, dalam bentuk skala.

2. Alat Ukur Motivasi Belajar: Alat pengumpulan data yang dipergunakan dalam penelitian ini adalah kuesioner, dalam bentuk skala. Alat ukur ini merupakan salah satu jenis alat pengumpulan data yang disampaikan kepada responden atau subyek penelitian melalui sejumlah daftar pernyataan tertulis yang berhubungan dengan variabel penelitian. Metode ini merupakan self-report yang digunakan karena kemudahan pelaksanaan, dimana subjek dapat mempertahankan anonimitasnya.

Alat ukur dalam penelitian ini terdiri dari pernyataan kuesioner isian dan tertutup (fixed alternative question), dengan bentuk skala Likert yang dimodifikasi dengan empat alternatif pilihan jawaban.

Pernyataan-pernyataan dalam skala terdiri dari pernyataan yang menyenangkan (favourable) dan tidak menyenangkan (unfavorable) Alat tersebut disusun berdasarkan teori yang dipergunakan dalam penelitian ini. Alat ukur motivasi belajar disusun berdasarkan teori Johnson\&Johnson, daftar pernyataan disusun dalam skala model "likert" yang dimodivikasi dari 5 alternatif jawaban menjadi 4 alternatif jawaban dengan pertimbangan untuk menghindari pernyataan ragu-ragu.

Untuk mengukur reliabilitas yang dihasilkan dari pengukuran motivasi belajar digunakan teknik Alpha Cronbach.

Validitas alat ukur adalah tingkat sesuatu alat ukur yang mampu mengukur apa yang hendak diukur
(Arikunto,2002) yang diperoleh melalui pengujian itemnya. Dengan menggunakan program SPSS diperoleh hasil 40 item valid dari 53 item alat ukur motivasi belajar. Dan 18 item valid dari 13 item untuk alat ukur gaya mengajar dosen.

\subsection{Metode Analisis}

Data Dalam penelitian ini akan dipergunakan berbagai uji statistik, baik dalam menganalisis uji coba alat pengumpulan data, metode analisis hasil data utama. Uji statistik akan menggunakan perangkat lunak komputer SPSS 16.0 (Yamin \& Kurniawan.2009)

Sebelum kuesioner digunakan sebagai alat pengumpul data dalam penelitian sesungguhnya, maka dilakukan pengujian validitas dan reliabilitas item. Pengujian validitas bertujuan untuk mengetahui nilai diskriminasi item, yaitu berapa besar nilai antar individu yang memiliki skor tinggi dan skor rendah pada suatu kriteria. Pengujian ini menggunakan teknik inter item consisteny, yaitu dengan menghitung korelasi skor item dengan skor total item. Teknik statistik yang digunakan adalah formula korelasi Pearson's Product Moment. Sedangkan pengujian reliabilitas kuesioner dilihat untuk melakukan seberapa jauh alat memberikan hasil yang relatif tidak berbeda bila dilakukan pengukuran kembali terhadap gejala yang sama. Perhitungan koefisien reliabilitas dilakukan dengan menggunakan teknik statistik Alpha Cronbach. Metode analis hasil data utama dalam rangka menjawab masalah operasional dari penelitian, dipergunakan uji korelasi Pearson's Product Moment.

\section{HASIL DAN PEMBAHASAN}

Berdasarkan hasil uji statistik yang telah dilakukan menunjukkan bahwa jika dikorelasikan secara keseluruhan gaya mengajar dosen dengan motivasi belajar, maka tidak terdapat hubungan antara kedua variabel tersebut. Tetapi ketika dikorelasikan masing-masing gaya mengajar dengan motivasi belajar ada hubungan dengan arah yang negatif. Hasil uji statistik menarik untuk dikaji secara konseptual. Gaya mengajar dosen dalam proses pembelajaran artinya gaya yang dimunculkan dosen dalam mengajar yang diberikan pada mata kuliah yang diajarkan pada mahasiswa. Ada empat gaya yaitu: elementary, intermediate, advanced dan creative-evaluative. Menurut Bloom (dalam Azwar 1996) cara yang diberikan dalam proses 
pembelajaran terhadap mahasiswa dengan menekankan pada cara understanding, comprehension dan memorizing pada mahasiswa termasuk gaya mengajar elementary. Cirinya adalah banyak menggunakan "what, when where" dalam menyampaikan informasi, menjelaskan tugas atau pekerjaan rumah. Hasil uji statistik yang mempunyai arah negatif jika dihubungkan dengan pendapat Gagne (1995) menunjukkan apapun gaya mengajar yang diberikan tidak pernah lepas dari tipe pola belajar yang dilakukan oleh mahasiswa. Dalam hal ini Gagne menerangkan ada tipe verbal association. Ketika dosen banyak menggunakan kata- kata "what, when where" dalam penyampaian informasi keilmuannya maka respon yang berupa motivasi belajar dapat menurunkan motivasi belajar mahasiswa. Kondisi ini tidak terlepas dari bagaimana information procesing orientation yang diberikann dosen dalam mengajar. Mahasiswa yang mendapat model mengajar ini mendapat transfer of knowledge dengan cara mengerti atau menghafal saja. Menurut pandangan aliran behaviorisme motivasi sebagai penggerak tingkah laku mahasiswa yang akan membuat respon apakah dapat materi pelajaran tersebut berguna bagi dirinya atau tidak, terkait dengan informasi yang berupa hafalan tersebut. Tetapi jika belajar tidak menimbulkan perubahan pada diri mahasiswa, maka hafalannya tidak akan menetap pada memorinya. (Muhibbin 1985). Gaya mengajar intermediate juga mempunyai hubungan yang negatif dengan motivasi belajar mahasiswa. Artinya dosen dengan gaya mengajar intermediate, menekankan pada critical thinking and doing. Ciri dalam proses pembelajaran diberikan dalam bentuk how, why and application, penjelasan, dialog, diskusi, kasus, presentasi. Pada proses pembelajaran ini mahasiswa diajak untuk mengkritisi secara ilmiah informasi yang ia terima. Dosen mengajarkan bagaimana menanggapi suatu pendapat berdasarkan logika berpikir yang dapat dipertanggungjawabkan. Menurut Suryabrata (1995) ada peran faktor eksternal antara lain wawasan atau aktivitasnya dilingkungan sosial yang digunakan mahasiswa ketika membuat suatu pandangan yang kritis terhadap suatu pendapat. Interaksi yang terjadi antara mahasiswa dengan dosen akan meningkatkan motivasi jika akan menumbuhkan kesadaran pada mahasiswa tentang pentingnya menerima hasil pandangan dirinya yang dikaitkan dengan pendapat temannya atau tokoh yang sedang dibahas. Hal ini akan menimbulkan naiknya " ego involment" atau harga diri bahwa ia dapat menanggapai secara ilmiah hal sedang dijelaskan oleh dosen (Sardiman 2001). Tetapi sebaliknya ketika ia menanggapi materi yang sedang dibahas dan dirasakannya sebagai hukuman, maka akan terjadi reinforcement yang negatif dan akan menurunkan motivasi belajarnya. Dosen dengan gaya mengajar advanced dengan ciri menekankan pada problem solving, why, analysis, sintesis dan idea. Dosen banyak membahas kasus, proyek, survey studi lapangan, presentasi dan seminar. Hasil uji statistik juga menunjukkan korelasi yang arahnya negatif. Pada gaya mengajar ini mahasiswa memiliki perencanaan dalam tiap tindakan karena tidak hanya faktor dari dalam dirinya yang berperan, tetapi juga faktor dari luar dirinya di saat terlibat problem solving untuk memecahkan suatu permasalahan yang diberikan dosen. Ketika menganalisis ia akan fokus pada tujuan yang perlu dicapai. Ia aktif untuk mencari informasi baru dan memanfaatkan umpan balik yang kongkrit dalam setiap tindakan yang dilakukan (Wolfolk, 1988). Sebaliknya jika dalam proses belajar dengan gaya mengajar advanced akan membuat ia cemas dan takut gagal akan menaikkan atau menurunkan motivasi belajarnya.

Dosen dengan gaya mengajar creative-evaluative, mengajarkan mahasiswa untuk menggunakan "thinking out of the box". Mengevaluasi, inovasi, membahas kasus, diskusi, penelitian, proyek, karya ilmiah, jurnal dan seminar. Pada proses pembelajaran dengan gaya mengajar ini mahasiswa diajak untuk berfikir tidak hanya sebatas teori yang ada dari buku, tetapi mahasiswa harus menemukan ide kreatif yang dapat dimunculkan terkait dengan materi yang diajarkan dosen. Di saat ia mampu menyelesaikan setiap tugas dengan cara di luar dari buku, artinya ia menemukan pendapatnya dalam praktek atau interaksinya di lapangan, maka ia akan puas dan bangga jika diberi penghargaan. Dengan kata lain ia berani tampil beda untuk berpendapat dalam menyelesaikan tugas yang diberikan. Semua langkah yang ia lakukan direncanakan, dan ia fokus pada penyelesaian masalah. Ketika kondisi ini terjadi, maka dapat menaikkan motivasi belajarnya. Dosen yang memberikan kesempatan pada mahasiswa untuk menggunakan kemampuan dari pengalaman, dan wawasannya, maka ia akan menjadi mahasiswa yang aktif mempelajari materi pelajaran yang diberikan oleh dosen. Ia mampu untuk memunculkan ide kreatifnya dalam menyelesaikan tugas yang diberikan oleh dosen, dan motivasinya menjadi naik untuk menyelesaikan tugas. Sebaliknya jika mahasiswa tidak dapat menggunakan kemampuan dari pengalaman dan wawasannya maka ia menjadi mahasiswa yang hanya diam menunggu materi pelajaran yang 
diberikan oleh dosen. Ia tidak mampu untuk memunculkan ide kreatifnya dalam menyelesaikan tugas dari dosen, dan motivasinya menjadi rendah.

Dari keempat gaya mengajar yang di gunakan oleh dosen yang korelasinya paling tinggi dengan motivasi belajar mahasiswa adalah gaya mengajar creative-evaluative. Hasil uji statistik dari penelitian ini menunjukkan bahwa gaya mengajar ini menjadi penentu paling dominan dibandingkan dengan gaya mengajar yang lain. Artinya keterlibatan mahasiswa dengan potensi dan kemampuan yang ia miliki ditambah dengan gaya mengajar dosen yang menekankan untuk berpikir : "out of the box" akan menentukan apakah mahasiswa motivasi belajarnya akan naik. Untuk mahasiwa yang menyukai tugas yang diperoleh tidak hanya dari teori akan membuat ia tertantang mengerjakan tugas tersebut. Dosen yang mengajar dengan gaya creative - evaluative perlu memetakan terlebih dahulu karakteristik mahasiswa yang kelolanya. Mahasiswa yang terbiasa dengan gaya mengajar ini akan menjadi mahasiswa unggulan dalam berfikir kreatif untuk memecahkan permasalahan yang dihadapinya. Selain gaya mengajar, hasil uji statistik menunjukkan ada perbedaan motivasi belajar antara mahasiswa Program Studi Healing dan Konseling. Program Studi Pendidikan Anak Usia Dini, dan Program Studi Psikologi. Motivasi belajar mahasiswa Healing dan Konseling lebih tinggi dari pada motivasi belajar mahasiswa Program Studi Pendidikan Anak Usia Dini dan Program Studi Psikologi. Motivasi belajar mahasiswa Program Studi Pendidikan Anak Usia Dini lebih tinggi dari pada motivasi belajar mahasiswa Program Studi Psikologi. Kondisi ini menunjukkan ada faktor yang menyebabkan terjadinya perbedaan tersebut. Menurut Wollfolk (1980) kondisi kelas yang dapat meningkatkan motivasi belajar relatif terorganisasi dan bebas dari gangguan atau kekacauan. Selain itu dosen harus sabar dalam mengajar, dan ia mampu memberikan materi pelajaran dengan cara melibatkan mahasiswa untuk aktif dalam proses pembelajaran dan tugas yang diberikan. Dari hasil observasi penulis, mahasiswa Program studi Healing dan Konseling memiliki rasa ingin tahu yang tinggi terhadap materi yang diajarkan di kelas dan mau terlibat aktif dalam setiap tugas atau kegiatan yang diberikan oleh dosen.
Di dalam proses pembelajaran, membangun kepercayaan dan harapan positif pada mahasiswa merupakan faktor penting yang berperan dalam meningkatkan motivasi belajar. Mahasiswa mengetahui dan memahami sistem nilai yang ia peroleh dalam proses pembelajaran, dan ia yakin dan mempunyai tujuan yang jelas mengapa ia perlu mempelajari materi yang diberikan oleh dosen.

Jika dosen memberikan umpan balik, mahasiswa akan memanfaatkannya untuk mencari informasi baru, dan rasa banggga dan puas akan muncul jika mereka dapat menunjukkan prestasinya. Tampilan tingkah laku mahasiswa yang tidak takut pada kegagalan, akan mendorong mereka untuk mencapai prestasi setelah diberikan umpan balik oleh dosen. Oleh karena itu gaya mengajar yang digunakan dosen menjadi penting untuk memunculkan motivasi belajar mahasiswa. Motivasi belajar bagi mahasiswa merupakan daya penggerak untuk bertingkah laku dalam belajar. Ketika daya pengggerak ini diperlukan dalam proses belajar berarti tujuan dari bertingkah laku terarah pada pencapaian prestasi dalam proses pembelajaran. Gaya mengajar Elementary mempunyai hubungan negatif dengan Motivasi Belajar (- $0.256<0.05)$ menurut Kountur R (2005) ada hubungan antara Gaya mengajar dengan motivasi belajar, arah hubungan yang negatif. Jika gaya mengajar elementary diberikan mempunyai hubungan dengan motivasi belajar. Gaya mengajar Intermediate mempunyai hubungan negatif dengan Motivasi Belajar $(-0.090<0.05)$ menurut Kountur R (2005) ada hubungan antara Gaya mengajar Intermediate dengan motivasi belajar arah hubungannya negatif. Jika gaya mengajar Intermediate diberikan berhubungan dengan motivasi belajar. Gaya mengajar advanced mempunyai hubungan negatif dengan Motivasi Belajar $(-0.313<0.05)$ menurut Kountur R (2005) ada hubungan antara Gaya mengajar dengan motivasi belajar, arah hubungan yang negatif. Jika gaya mengajar elementary diberikan mempunyai hubungan dengan motivasi belajar. Gaya mengajar Evaluation mempunyai hubungan negatif dengan Motivasi Belajar $(-0.256<0.05)$ menurut Kountur R (2005) ada hubungan antara Gaya mengajar Evaluation dengan motivasi belajar, arah hubungan yang negatif. Jika gaya mengajar Evaluation diberikan mempunyai hubungan dengan motivasi belajar. 


\section{KESIMPULAN DAN SARAN}

\subsection{Kesimpulan}

Dari hasil penelitian yang telah dilakukan, maka diperoleh suatu kesimpulan sebagai berikut:

1. Tidak ada hubungan antara gaya mengajar dosen dengan motivasi belajar mahasiswa

2. Tidak ada hubungan antara gaya mengajar dosen dengan motivasi belajar mahasiswa Program studi PAUD

3. Tidak ada hubungan antara gaya mengajar dosen dengan motivasi belajar mahasiswa Program studi Psikologi

4. Tidak ada hubungan antara gaya mengajar dosen dengan motivasi belajar mahasiswa Program studi Healing dan Konseling.

5. Ada hubungan dengan arah negatif gaya mengajar elementary dengan motivasi belajar mahasiswa

6. Ada hubungan dengan arah negatif gaya mengajar intermediate dengan motivasi belajar mahasiswa.

7. Ada hubungan dengan arah negatif gaya mengajar advanced dengan motivasi belajar mahasiswa

8. Ada hubungan dengan arah negatif gaya mengajar evaluation dengan motivasi belajar mahasiswa

9. Gaya mengajar advanced dengan menekankan pada problem solving, why,analysis,syntesis dan idea, banyak membahas kasus, proyek, survey, studi lapangan,presentasi dan seminar lebih dapat mendukung peningkatan motivasi belajar mahasiswa.

10. Motivasi belajar mahasiswa Program Studi Healing dan Konseling lebih tinggi dari pada motivasi belajar mahasiswa Program studi Psikologi dan PAUD.

\subsection{Saran:}

Saran yang dapat diberikan dari hasil penelitian ini adalah:

1. Dosen sebaiknya dapat memberikan gaya mengajar yang dapat meningkatkan motivasi belajar mahasiswa. Antara lain dengan cara mengikut sertakan mahasiswa aktif dalam perkuliahan yang diberikan.

2. Sebaiknya dosen menghindari gaya mengajar elementary hanya menggunakan "what, when, where", penyampaian informasi, menjelaskan tugas, pekerjaan rumah.

3. Sebaiknya dosen menghindari gaya mengajar intermediate, yang dalam proses pembelajaran menekankan pada how, why and application, penjelasan, dialog, diskusi, kasus, presentasi saja.

4. Sebaiknya dosen lebih banyak menggunakan gaya mengajar advanced, dengan lebih menekankan pada problem solving, why, analysis, synthesis dan idea. Banyak membahas kasus, proyek, survey, studi lapangan presentasi dan seminar.

5. Dosen perlu sabar ketika ada hal yang dianggap dapat mengganggu jalannya perkuliahan dikelas. Karena situasi kelas menjadi faktor penting untuk memunculkan motivasi belajar.

6. Gaya mengajar yang diberikan sebaiknya dilakukan evaluasi oleh pihak terkait, agar diperoleh hasil yang maksimal dalam proses pembelajaran.

7. Dosen perlu diikut sertakan training tentang proses pembelajaran dan gaya mengajar.

\section{DAFTAR PUSTAKA}

[1] Arikunto. 2002. Prosedur Penelitian . Suatu Pendekatan Praktek.Jakarta: Rineka Ci

[2] Atkinson, R.L.Richard, E.E.S.Dary, I.J.B.M. 1996. Introduction to Psychology. New York: Harcout Beace College Publishing.

[3] Azwar,S. 2000. Tes Prestasi.Fungsi dan Pengembangan Pengukuran Prestasi Belajar. Yogyakarta : Pustaka Pelajar.

[4] Kartikawan, I, A, N. 2007. Peran Program Academic acheivement Behavior Training (AABT) Terhadap Perubahan Motif Berprestasi Pada Mahasiswa Underachiever. Jurnal Psikomedia. Bandung: Fakultas Psikologi Universitas Kristen Maranatha.

[5] Djiawandono, S.E.W. 2002. Psikologi Pendidikan. Jakarta : Gramedia Widisarana Indonesia.

[6] Once.2008. Peningkatan Kemampuan Dosen Dalam Proses Pembelajaran.Jakarta: UBM

[7] Purwanto, N. 2007. Psikologi Pendidikan. Bandung: Remaja Rosdakarya.

[8] Rumiati. 2006. Prokrastinasi Akademik Ditinjau dari Motivasi Berprestasi dan Stress mahasiswa. Jurnal Psikologi.Semarang: PS Psikologi Fakultas Kedokteran Universitas Diponogoro.

[9] Roebyantho,S,H. 2008.Hubungan Antara Minat Membaca dengan Prestasi Belajar Pada Mata Kuliah Psikologi Kepribadian mahasiswa Fakultas Psikologi "ABC" Jakarta. Jurnal Psibernetika.Vol.1.No.1,Hal.43-60; ISSN: 19793707

[10] Santrock,J,W. Psikologi Pendidikan Jakarta:Rajawali

[11] Syamsuddin,A.1990. Pedoman Studi Psikologi Kependidikan. Bandung : IKIP 
[12] Sugiyono. 2007. Metode Penelitian Bisnis. Bandung: C.V. Alfabeta

[13] Suwarni,E.2008. Hubungan Antara Persepsi Terhadap Metode Mengajar Dosen Dengan Motivasi Belajar mahasiswa UBM Jakarta. Jurnal Psibernetika. Vol 1, No 2, Hal: 1 - 21 ; ISSN: 1979-3707

[14] Wahyuni I..2003. Hubungan Antara Persepsi Terhadap Jurusan Psikologi Dengan Motivasi Belajar Pada Mahasiswa Psikologi IAIN Sunan Gunung Jati Bandung. Skripsi. Tidak diterbitkan
[15] Woolfolk, A.E. 1995. Educational Psychology. Boston : Allyn and Bacon.

[16] www.wikipedia.com

[17] www.google.com

[18] www.idonbiu.com/2009/10.latar-belakangmasalah-pendidikan-Indonesia 